\title{
Production and characterization of co-composted biochar and digestate from biomass anaerobic digestion
}

\author{
David Casini ${ }^{2}$. Tommaso Barsali ${ }^{1} \cdot$ Andrea Maria Rizzo $^{1} \cdot$ David Chiaramonti $^{1,2}$ (B) \\ Received: 30 March 2019 / Revised: 15 July 2019 / Accepted: 16 July 2019 / Published online: 27 July 2019 \\ (C) The Author(s) 2019
}

\begin{abstract}
Biochar, produced through pyrolysis of lignocellulosic biomass, is attracting increasing interest as soil amendment thanks to its potential numerous benefits to agriculture, as well as its ability to sequester carbon in soil. Solid fraction of digestate from anaerobic digestion is a well-known N-rich substrate, most often composted in large and small agro-industrial plants. Cocomposting biochar and digestate has the potential to synergistically increase the agronomic value of both components: however, it needs further process and on-field research. The present research work reports on the experimental tests on producing biochar and co-composting various biochar amounts with digestate from biomass anaerobic digestion (product here named COMBI). Biochar was produced by feeding wood chips from chestnut to an innovative oxidative reactor. In order to evaluate the quality of the products obtained by composting and co-composting, correlating this with the final biochar rate in the material, the net organic matter yield, the humified organic matter, the compliance with the European Compost Network Quality Assurance Scheme (ECN-QAS) limits for inorganic pollutants, and the product stabilization and sanitization indexes were investigated. The $11.2 \% \mathrm{w} / \mathrm{w}$ d.b. biochar rate in the initial blend $(19.8 \% \mathrm{w} / \mathrm{w}$ d.b final concentration in the co-composted products) offered the best performances and is recommended for further investigation. Additional benefits from co-composting were also assessed, as the reduced dust load that favors safety and health during logistics and use.
\end{abstract}

Keywords Biochar $\cdot$ Compost $\cdot$ Digestate $\cdot$ Co-composting $\cdot$ Soil amendment

\section{Introduction}

Sustainable production of biomethane is a key option to substitute conventional natural gas and decarbonize the energy system [1]: anaerobic digestion (AD) is the leading route to generate biogas, which can then be further upgraded to biomethane by $\mathrm{CH} 4$ separation. Today, the $\mathrm{AD}$ process is a well-mature process, bringing environmental and social benefits at both local and global level $[2,3]$ : the main co-product of biomass anaerobic digestion is a sludge (digestate), which

Electronic supplementary material The online version of this article (https://doi.org/10.1007/s13399-019-00482-6) contains supplementary material, which is available to authorized users.

David Chiaramonti

david.chiaramonti@unifi.it

1 Renewable Energy COnsortium for R\&D (RE-CORD) Viale J. F. Kennedy, 182, Scarperia e San Piero, 50038 San Piero, Italy

2 CREAR/Department of industrial Engineering, University of Florence, Viale Morgagni 40, 50134 Florence, Italy can be applied to soil for agronomic purposes as an organic amendment. Composting is another well-known pathway to stabilize organic matter of various origins through a biooxidative process [4], which brings benefits as volume reduction, sanitization from pathogens, reduction of liquid contaminants, and economic and environmental returns $[5,6]$. In anaerobic digestion plants, the composting stage of the solid fraction of digestate generally occupies large volumes and requires long residence time, in addition to complex logistical steps $[7,8]$. The addition of a bulking agent in the compost pile is normally recommended, in particular when substrates as digestates are used. The small particle size of the material generates risks of anaerobic conditions within the pile, leading to the production of undesired phenomena as ammonia volatilization $[9,10]$.

Biochar is the solid product from lignocellulosic biomass pyrolysis, characterized by a high content of stable $\mathrm{C}$, mostly produced through slow pyrolysis. Biochars from intermediate/ fast pyrolysis and gasification are often discussed in literature, even if these show different characteristics. Biochar is a highly porous material with a wide range of possible uses, including 
sustainable agriculture, as it improves the water-holding capacity and the organic matter content in soil [11-13]. This feature is particularly interesting in marginal lands and regions where rain is scarce, and irrigation is difficult for a number of environmental or economic reasons [13, 14]. Co-composting of organic matter and biochar, if compared to conventional composting, can positively affect the composting residence time, reducing both $\mathrm{N}$-compound losses in the atmosphere and leaching, favoring the microbiological activity and in turn increasing the humification process, eliminating or reducing the need for additional bulking agent [15-18]. Biochar, alone or co-composted, also contributes to long-term atmospheric $\mathrm{C}$ sequestration in soil, offering a rather low-complexity solution if compared to most of the available $\mathrm{C}$ sequestering state-ofthe-art technologies [19, 20]. Sanchez-Monedero et al. [21] reviewed biochar applications to composting, suggesting application rates at the beginning of the co-composting process: the proposed rate was approximately equal to $10 \%$ by weight on dry basis of the composting pile. This amount seemed to optimize the process performances, but the suggested range bringing positive results to the process was indicated among a minimum of $3 \%$ to a maximum of $20 \% \mathrm{w} / \mathrm{w}$ on dry basis [21].

This study examines the integration of slow pyrolysis and biomass anaerobic digestion through a pyrolysis and cocomposting experimental investigation. Co-composting [22-26] was performed using solid fraction of digestate from biomass $\mathrm{AD}$, straw, and various rates of biochar. Feedstocks and products were characterized, deriving conclusions for future works and applications.

\section{Materials, methods, and analytical results}

\subsection{Analytical methods and main results of feedstock characterization}

Analytical characterization of feedstock and products have been carried out according to the main European methods for biochar and compost as agricultural soil amendments; in particular, the European Biochar Certification (EBC) methods and the European Compost Network Quality Standards (ECN-QAS) $[25,26]$ were adopted. Feedstock characterization results and standards for analysis used are collected in the supplementary material document (online resource).

COMBI was produced through co-composting blends of biochar with digestate solid fraction, and the addition of a small and variable (for the different cases) amount of cereal straw as bulking agent. Biochar was produced in the oxidative CarbOn pilot plant developed by RE-CORD. CarbOn is a continuous biomass carbonization system based on open top, downdraft technology, operating under oxidative pyrolysis regime. The plant is rated for $50 \mathrm{~kg} \mathrm{~h}^{-1}$ of biomass with up to $20 \% \mathrm{w} / \mathrm{w}$ moisture content at inlet. The reactor is externally insulated and consists of a cylindrical volume where biomass is converted in a controlled oxidative environment in the temperature range of $500-750{ }^{\circ} \mathrm{C}$, with a solid residence time of approx. $3 \mathrm{~h}$ in the reactor and $2 \mathrm{~h}$ in the cooled discharge. A more detailed description of the process and the pilot plant can be found elsewhere $[27,28]$. The feedstock used for the production of biochar for this work was chestnut (Castanea sativa Mill.): the main chemical and physical characterization can be found in Table 9 (online resource). The experimental conditions during biochar production in the CarbOn unit are reported in Table 1.

The obtained product was sampled according to EBC standards, and results of the analysis for biochar characterization can be found in Table 10 (online resource). .

The characterization of the biochar produced and used in the present study confirms that it qualifies for the EBC premium grade quality. In addition to the evaluation of the total specific surface area (nitrogen-based BET method) for surface and porosity characterization, a density functional theory (DFT) analysis was also performed to assess the pore size distribution. This investigation showed a biochar porosity structure mainly composed by micropores having diameters lower than $2 \mathrm{~nm}$, and mesopores with diameters ranging from 2 to about $4 \mathrm{~nm}$. Detailed results of the DFT analysis can be found in Fig. 3 (online resource).

The biochar is mostly very stable carbon to thermochemical and biological degradation, only marginally subject to mineralization by microorganisms $[19,29]$. As reported by Leng et al., biochar fixed carbon (BFC) is closely related to stable $\mathrm{C}$ content. Calvelo Pereira et al. showed how the thermogravimetric analysis (TGA) can be a suitable and practical mean to evaluate both the stable and the labile carbon fractions (respectively fixed carbon and volatile matter content of biochar) [19, 30, 31].

Concerning the collection of organic matter (OM) for subsequent co-composting with biochar, digestate was supplied by an industrial anaerobic digestion plant located in the North of Italy, mainly fed with manure as main feedstock. The characterization of the digestate can be found in Table 11 (online resource).

The analysis of the Potential Dynamic Respirometric Index (PDRI) of the digestate suggests a well-stabilized organic matrix available at the outlet of the anaerobic process, collected after mechanical dewatering.

Table 1 Experimental conditions for biochar production in the CarbOn pilot unit [27]

\begin{tabular}{ll}
\hline Operating condition & Slow oxidative pyrolysis \\
\hline Inlet feed & $50 \mathrm{~kg}_{\text {w.b. }} \mathrm{h}^{-1}$ \\
Maximum process temperature & $550{ }^{\circ} \mathrm{C}$ \\
Residence time & $3 \mathrm{~h}$ \\
\hline
\end{tabular}


The water content of the solid fraction of the digestate was also a key parameter to be analyzed: it was measured at $63 \%$ $w / w$. According to applicable standards, the presence of pathogens (Salmonella spp. and Escherichia coli) also need to be assessed, but no biological contamination was detected.

The characterization of the bulking agent cereal straw, which is normally used as horse bedding stable, can be found in Table 12 (online resource).

\subsection{Co-composting method and main characterization of windrows/piles}

The co-composting process adopted in the present work followed the ECN-QAS recommended procedures [26] and was performed during the summer season in a farm located in Scandicci (Florence), Italy. The experiment duration was 60 days, with no additional curing time also keeping into account the time constraints for the planned soil application operations (November 2018) and field agronomic trials.

The composting system adopted for the present work was a static one, with windrows formed within a farm-greenhouse (Fig. 1), and manually turned twice per week. All windrows were prepared for the test at the same time and in the same environment by the same operators; samples for analysis were taken at day 0 and day 60 . Windrows dimensions were approximately $2 \mathrm{~m}$ (length) $\times 1.6 \mathrm{~m}$ (width) $\times 0.8 \mathrm{~m}$ (height), creating a pile of about $1.5 \mathrm{~m}^{3}$ of volume with a vertical section as similar as possible to a semicircular shape. Windrows were prepared starting from a first layer of digestate and finishing them with digestate covering the entire pile. Biochar and straw layers were separated by digestate layers. At the end of the windrows preparation, all piles accounted for the same volume. This layer configuration lasted until the first turning, which occurred after a week. Temperatures were collected before windrow turning by positioning three probes in each pile at one-third of the vertical section from the soil and at one fourth, half, and three-fourths of the horizontal section. Ambient temperature and humidity were not recorded inside the greenhouse due to practical constraints. However, in Fig. 5 (online resource), the average daily temperature and relative humidity of Scandicci (Florence, Italy) are reported, taking data from the meteorological station managed by SIR (Servizio Idrologico della Regione Toscana), an organizational unit of the Tuscany Region. Daily average temperature and daily average relative humidity values are compared to $\mathrm{CD}$ and CB2 average windrow temperature. The daily average values of temperature and relative humidity at the meteorological station can be a good approximation of those at the greenhouse, because of their physical proximity (Scandicci, Florence, Italy), and the greenhouse itself can be considered as an open tunnel (as shown in Fig. 1).

Four different blends were considered for composting, one for each windrow. The rates of biochar were increased from 0 to $15.2 \%$ by weight on dry basis, for the reasons explained below related to field rate application. Correspondingly, the rates of straw and digestate were decreasing, keeping the initial goals of four windrows with the same volume. The windrows were named $\mathrm{CD}$ (digestate and straw only) $\mathrm{CB} 1$ (digestate, straw and $12 \mathrm{~kg}$ w.b. of biochar), CB2 (digestate, straw and $18 \mathrm{~kg}$ w.b. of biochar), and CB3 (digestate, straw and $24 \mathrm{~kg}$ w.b. of biochar), as detailed in Table 2 . The $18 \mathrm{~kg}$ w.b. rate of biochar was selected for CB2, as it corresponds to an application rate of $3 \mathrm{t} \mathrm{ha}^{-1}$ w.b. of biochar for the case of agronomic field trials in $60-\mathrm{m}^{2}$ plots. The $12-\mathrm{kg}$ w.b. and $24-$ $\mathrm{kg}$ w.b. rate of biochar for CB1 and CB3, respectively, were used to investigate the effects of different doses of biochar in windrows. The biochar percentage by weight - on dry basisof the starting composting piles - is thus mainly related to the digestate humidity as received.

The measured $\mathrm{C} / \mathrm{N}$ index of the $\mathrm{CD}$ pile was equal to 36.3 , close to the optimal value for composting reported in literature $[32,33]$; in general, higher $\mathrm{C} / \mathrm{N}$ values of the initial matrix can lead to extend the duration of the composting process [34]. Compared to the control $\mathrm{C} / \mathrm{N}$ ratio (i.e., the $\mathrm{C} / \mathrm{N}$ value for the $\mathrm{CD}$ pile), the other piles (CB1, CB2, and CB3) showed higher ratios, increasing with the addition of the biochar, which however gives the main contribution in terms of stable and recalcitrant $\mathrm{C}$. The measured initial moisture content fall within the range indicated by literature, i.e., between 50 and $60 \%$ in mass fraction $[33,35,36]$. While the $\mathrm{pH}$ of the digestate, the main substrate matrix, was equal to 7.00 , the $\mathrm{pH}$ of biochar was 7.97; this led to reaching an optimum environment for the
Fig. 1 Farm-scale co-composting site - windrows and piles
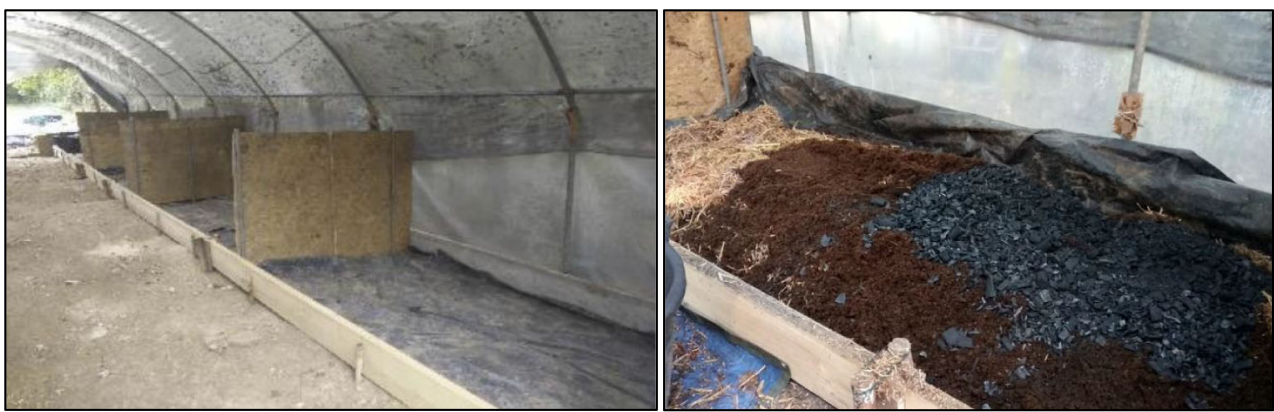
Table 2 Initial windrows compositions

\begin{tabular}{llrrrr}
\hline & U.M. & CD & CB1 & CB2 & CB3 \\
\hline Windrow & kg d.b. & 160.6 & 156.5 & 153.0 & 149.6 \\
Starting moisture & $\% w / w$ w.b. & 61.6 & 60.0 & 59.2 & 58.3 \\
Biochar content & kg w.b. & 0.0 & 12.0 & 18.0 & 24.0 \\
Biochar rate & $\%$ w $w$ d.b. & 0.0 & 7.3 & 11.2 & 15.2 \\
C/N index & & 36.3 & 40.4 & 42.7 & 45.2 \\
\hline
\end{tabular}

microbiological activity, as also reported by de Bertoldi et al., which explained how $\mathrm{pH}>7.5$ can lead to higher amount of ammonia volatilization [16, 37].

The presence of coliforms, as $E$. coli, was also investigated in the digestate and the different composted products: this analysis was carried out according to APAT CNR IRSA 7030 F Man 292003 method. Finally, humic substances content were assessed according to the Regione Piemonte method C 6.3-1998.

Replications of windrows were not possible due to time, space constraints in the greenhouse, and availability of feedstock on short notice. Nevertheless, COMBI was properly sampled at the end of the co-composting process (it was turned manually by operators twice per week) taking sample material from different sections and all along the length of every windrow: three vertical sections were chosen to collect material for analysis (the ones where temperatures probes are located, as described before). Furthermore, the material collected for every section was taken at different height, considering also the external layer. After the sample homogenization, they were analyzed in our laboratory following relative standards for all the analysis chosen (where triplicates are required in most of the cases).

\section{Results and discussion}

The average temperature for each windrow, as recorded twice a week, before each turning are reported at Fig. 2. Temperatures trends show that maximum temperatures are all falling in a comparable range and above the $55{ }^{\circ} \mathrm{C}$ target. The highest peak temperature was reached by $\mathrm{CD}\left(58^{\circ} \mathrm{C}\right)$, while the lowest temperature level was observed for $\mathrm{CB} 3$ $\left(55.6^{\circ} \mathrm{C}\right)$. However, $\mathrm{CB} 2$ and $\mathrm{CB} 3$ reached peak temperatures at least 4 days earlier then control $\mathrm{CD}$ and $\mathrm{CB} 1$. The biooxidative phase of $\mathrm{CB} 2$ and $\mathrm{CB} 3$ lasted for $\sim 15$ days, while $\mathrm{CD}$ and $\mathrm{CB} 1$ needed $\sim 19-20$ days to reach the same temperature levels.

The range of $52-60{ }^{\circ} \mathrm{C}$ is considered as the most appropriate for adequate treatment of the OM [33, 38]. However, ECN-QAS for compost operation quality manual recommends 10 days over $55^{\circ} \mathrm{C}$ or 3 days above $65{ }^{\circ} \mathrm{C}$ for full

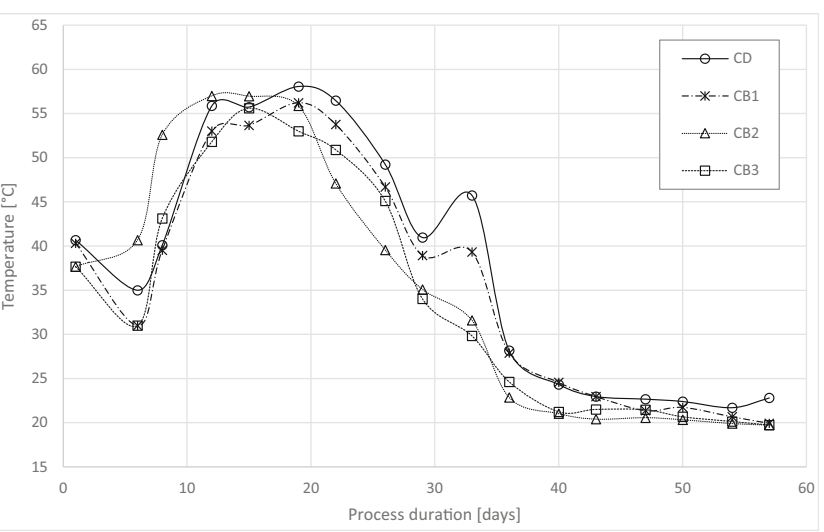

Fig. 2 Average temperatures for each windrow during the co-composting process. The graph shows the peak temperatures reached during the oxidative phase and how the values stabilize gradually to the ambient temperature

sanitization of the substrate from human pathogens in open systems [26].

Nevertheless, even if the peak temperature of $55^{\circ} \mathrm{C}$ was reached in each windrow, the duration of this phase lasted for at least 10 days only in the case of CD and CB2. In order to verify the full sanitization of the products, they were all analyzed for biological contamination by Salmonella spp. The outcome was positive, with all samples resulting pathogen free. However, due to the nature of the main substrate utilized, digestate from manure, this study also investigated the presence of coliforms (E. coli): all products showed coliform concentrations below $10 \mathrm{UFC}^{-1}$, excluding the case of $\mathrm{CB} 3$, which presented a proliferation of $10^{4} \mathrm{UFC}^{-1}$, probably due to a contamination during the co-composting process.

The characterization of the four products according to ECN-QAS quality standards is presented in Table 3.

Two further parameters (impurities, weed seed) were not analyzed (even if recommended by ECN-QAS), as the initial materials were substantially free from these thanks to the intrinsic nature of the feedstocks and the upstream processes (slow pyrolysis for biochar production, and anaerobic digestion for digestate). Furthermore, the experiment was conducted under greenhouse conditions, minimizing the risk of external seed contamination. Plant response, instead, is the subject of ongoing agronomic studies, whose results are not yet published. Maximum particle size was substituted by granulometry distribution analysis, presented in Table 4.

It should be noted that limits concerning OM content, contamination, and inorganic pollutants were met by all blends, which would thus qualify for commercial uses in the EU. Further analysis was however performed to better characterize the products in relation to the initial biochar content of the windrows, in particular as regards the OM transformation (Table 4). The water content of the COMBI blends was reduced by $9.8 \%, 11.5 \%, 9.5 \%$, and $5.7 \%$ for $\mathrm{CD}, \mathrm{CB} 1, \mathrm{CB} 2$, and $\mathrm{CB} 3$, respectively, if compared to the initial moisture. 
Table 3 COMBI characterization and including threshold following ECN-QAS quality standards [26]

\begin{tabular}{|c|c|c|c|c|c|c|}
\hline Parameter & U.M. & $\mathrm{CD}$ & CB1 & $\mathrm{CB} 2$ & CB3 & Method \\
\hline $\begin{array}{l}\text { Organic matter } \\
\text { Limit: } O M \geq 15\end{array}$ & $\% w / w$ d.b. & 75.47 & 81.34 & 81.49 & 82.03 & $\begin{array}{l}\text { CNR IRSA } 2 \text { Q64 } \\
\text { Vol } 22008\end{array}$ \\
\hline Liming value $(\mathrm{CaO})$ & $\% w / w$ d.b. & 2.67 & 2.23 & 1.74 & 3.36 & $\begin{array}{l}\text { EPA 3051A } 2007 \text { + EPA } \\
\text { 6010D } 2014\end{array}$ \\
\hline Total N & $\% w / w$ d.b. & 4.19 & 2.84 & 2.69 & 2.41 & EN 15104 \\
\hline Total P & $\mathrm{mg} \mathrm{kg}^{-1}$ d.b. & 11,353 & 7599 & 2826 & 2873 & EN 15290 \\
\hline Total K & $\mathrm{mg} \mathrm{kg}^{-1}$ d.b. & 25,568 & 22,215 & 17,405 & 16,656 & EN 15290 \\
\hline Total Mg & mg kg ${ }^{-1}$ d.b. & 7737 & 6917 & 4813 & 5452 & EN 15290 \\
\hline Bulk density & $\mathrm{g} \mathrm{l}^{-1}$ w.b. & 160 & 160 & 150 & 160 & EN 15103 \\
\hline Dry matter & $\% w / w$ w.b. & 48.2 & 51.5 & 50.3 & 48.0 & EN 14346 \\
\hline Electrical conductivity & $\mathrm{mS} \mathrm{cm}{ }^{-1}$ & 3.57 & 2.47 & 2.85 & 2.41 & ANPA 9 Man 32,001 \\
\hline $\mathrm{pH}$ value & & 8.2 & 8.6 & 8.2 & 8.3 & CNR IRSA 1 Q64 Vol 31985 \\
\hline Aerobic biological activity & $\mathrm{mg} \mathrm{O}_{2} \mathrm{~kg}_{\mathrm{OM}}{ }^{-1} \mathrm{~h}^{-1}$ & 270 & 350 & $<200$ & $<200$ & UNI 11184:2016 \\
\hline Salmonella (absence in $25 \mathrm{~g}$ d.b.) & & absent & absent & absent & absent & APAT 3 Man 202003 \\
\hline Inorganic pollutants & $\mathrm{mg} \mathrm{kg}^{-1}$ d.b. & & & & & \\
\hline $\mathrm{Pb}<130$ & & b.d.l. & b.d.1. & b.d.l. & b.d.l. & EN 15290 \\
\hline $\mathrm{Cd}<1.3$ & & b.d.l. & b.d.l. & b.d.l. & b.d.l. & EN 15290 \\
\hline $\begin{array}{l}\mathrm{Cr}<60 \\
\mathrm{Cu}<300\end{array}$ & & 20 & 7 & 5 & 6 & EN 15290 \\
\hline $\mathrm{Ni}<40$ & & 37 & 24 & 21 & 24 & EN 15290 \\
\hline $\mathrm{Hg}<0.45$ & & 5 & 1.2 & b.d.l. & b.d.l. & EN 15290 \\
\hline \multirow[t]{2}{*}{$\mathrm{Zn}<600$} & & $<0.1$ & $<0.1$ & $<0.1$ & $<0.1$ & $\begin{array}{l}\text { EPA 3051A } 2007 \text { + EPA } \\
\quad \text { 1631E } 2002\end{array}$ \\
\hline & & 196 & 153 & 143 & 142 & EN 15290 \\
\hline
\end{tabular}

However, no water was added during the experiment and the ambient average relative humidity value of the location area, where the test was carried out, at the end of the experiment was $66.1 \%$ (see Fig. 5, online resource).

The stabilization of organic substrates through the composting process is the result of both degradation and humification of the organic matter (OM), leading to a final content of $\mathrm{OM}$ in composted material lower than in the initial windrow, which can be considered a measure of the intensity of the composting process [33, 39]. The OM content was analyzed in all samples, and a mass balance analysis was performed, considering the dry-weight reduction of the windrows, as recommended by M.P. Bernal et al. [33, 40]. Results are presented in Table 5.

As fixed carbon increases with the biochar content in the initial blend, due to the stable and recalcitrant form of $\mathrm{C}$ added with biochar, this fixed carbon amount remains substantially the same during the short-time co-composting process (60 days) $[19,29,31]$. Therefore, in order to adopt a measure representative for the OM yield, the amount of biochar-fixed carbon
Table 4 Combi blends - other analysis

\begin{tabular}{lllllll}
\hline Parameter & U.M. & CD & CB1 & CB2 & CB3 & Method \\
\hline Water content & $\% w / w$ w.b. & 51.8 & 48.5 & 49.7 & 52.0 & EN 14346 \\
Volatile matter & $\% w / w$ d.b. & 55.5 & 47.8 & 20.7 & 19.4 & EN 15148 \\
Fixed carbon & $\% w / w$ d.b. & 24.2 & 30.1 & 29.9 & 33.8 & EN 1860-2 \\
Ash & $\% w / w$ d.b. & 20.3 & 22.1 & 20.7 & 19.4 & EN 14775 \\
Total C & $\% w / w$ d.b. & 40.0 & 45.4 & 45.2 & 50.8 & EN 15104 \\
Inorganic C & $\% w / w$ d.b. & 0.4 & 0.3 & 0.3 & 0.3 & EN 13654-2 \\
Organic C & $\% w / w$ d.b. & 39.6 & 45.1 & 44.9 & 50.5 & - \\
Granulometry & $>5$ mm \%wt & 21.4 & 27.5 & 21.3 & 33.0 & UNI EN 15149 \\
& $>2 \mathrm{~mm} \%$ wt & 13.4 & 17.2 & 18.5 & 15.9 & \\
& $>0.5 \mathrm{~mm} \% \mathrm{wt}$ & 42.2 & 35.1 & 38.3 & 32.3 & \\
& $<0.5 \mathrm{~mm} \% \mathrm{wt}$ & 23.0 & 20.2 & 21.9 & 18.9 & \\
\hline
\end{tabular}


Table 5 Product quality comparison: net organic matter (NOM) yield for every blend

\begin{tabular}{llllll}
\hline & & CD & CB1 & CB2 & CB3 \\
\hline BFC & kg d.b. & 0.0 & 9.2 & 13.8 & 18.4 \\
NOM in & kg d.b. & 138.9 & 127.1 & 120.0 & 112.9 \\
NOM out & kg d.b. & 53.4 & 53.2 & 56.5 & 63.6 \\
NOM yield & $\%$ & 38.5 & 41.8 & 47.1 & 56.3 \\
\hline
\end{tabular}

(BFC) was subtracted from the total OM content (Table 3), defining the new parameter net organic matter (NOM). NOM at the end of the process, expressed as a percentage of the initial NOM, increased almost linearly with the initial biochar rate added to the compost pile ( $\mathrm{CB} 3>\mathrm{CB} 2>\mathrm{CB} 1>\mathrm{CD})$.

A higher percentage of $\mathrm{OM}$ in the composted material with higher percentages of biochar could lead to assume that cocomposting negatively influences the intensity of the biooxidative phase, thus lowering the rate of degradation and stabilization of the OM in the initial material. However, three parameters listed below (PDRI, Humification $\mathrm{NH}_{4}-\mathrm{N} / \mathrm{NO}_{3}-\mathrm{N}$ ratio) show a stabilized compost for all the blends.

The measure of the Potential Dynamic Respiration Index (PDRI) showed better stabilization for CB2 and CB3. Specific oxygen uptake rate is in fact a direct parameter to assess the compost stabilization at the end of the process. Following Bernal et al., which refer to the Californian Compost Quality Council (CCQC) maturity index [33, 41], PDRI values above $1000 \mathrm{mg} \mathrm{O}_{2} \mathrm{kgOM}^{-1} \mathrm{~h}^{-1}$ are representative of unstable compost, while below $300 \mathrm{mg} \mathrm{O}_{2} \mathrm{kgOM}^{-1} \mathrm{~h}^{-1}$, the compost is considered as very stable. CB1 showed the highest value, with $350 \mathrm{mg} \mathrm{O}_{2} \mathrm{~kg}_{\mathrm{OM}}{ }^{-1} \mathrm{~h}^{-1}$, while the others resulted below the reference limit. However, it should be noted that only $\mathrm{CB} 2$ and CB3 showed PDRI $200 \mathrm{mg} \mathrm{O}_{2} \mathrm{kgOM}^{-1} \mathrm{~h}^{-1}$.

Other parameters can also be investigated in order to evaluate the bio-stabilization level of the products, such as humic acid (HA) and fulvic acid (FA) content, which are representative of the humification degree. A higher degree of humic substances correspond to a more efficient stabilization of the OM during composting [42]. HA and FA are heterogeneous complexes which can be classified by molecular weight, functional groups, and degree of polymerization and cyclization $[33,43,44]$. The four blends were analyzed for humic substance content and the results are shown in Table 6. CB1 content of HA and FA was the lowest observed, although comparable with $\mathrm{CD}$. CB2 values for HA and FA were the highest. CB3 showed the lowest HA value and intermediate FA value. These results suggest that the amount of biochar in the initial windrow does not allow a linear prediction of the HA and FA content, and that the CB2 windrow apparently maximized the synergistic effects of co-composting on the microbial humification processes.

As reported in the table above, the two main indexes used in this study to evaluate the humification level of the four blends, following Roletto et al. [43], were the Humification Index (HI, representing the ratio between HA and organic carbon contents) and the Polymerization Index (PI, representing the ratio between HA and FA). HI, in this paper, was calculated considering NOM as the organic carbon content, thus excluding the fixed carbon content of the amount of biochar used in blends. All products showed $\mathrm{HI}$ index higher than the minimum reference threshold, but while the control $\mathrm{CD}$ and $\mathrm{CB} 1$ showed comparable $\mathrm{HI}$ values, $\mathrm{CB} 2$ and $\mathrm{CB} 3$ showed a humification index at least three times higher than the previous ones. PI resulted below the limit only for the case of $\mathrm{CB} 3$, whereas the other samples showed comparable values.

A high level of $\mathrm{NH}_{4}-\mathrm{N}$ forms is an indication of a low stabilization for the OM. The fate of nitrogen forms varies along the composting process: the $\mathrm{NH}_{4}-\mathrm{N}$ form is prevailing during the mineralization processes of the OM, typical of the bio-oxidation phase.

As shown in Table 7, the $\mathrm{NH}_{4}-\mathrm{N}$ contents for all the blends fall below the limit of $0.04 \% w / w$ d.b. proposed by Zucconi and de Bertoldi [45] for mature compost (though from the organic fraction of municipal solid wastes), even if the same parameter for $\mathrm{CD}$ was at least three times the other blends. On the other hand, since nitrification of ammonium mostly occurs after the thermophilic phase, $\mathrm{NO}_{3}-\mathrm{N}$ concentration can also be retained as a good indicator of compost stabilization. Bernal et al. [46] proposed a limit of 0.16 to the $\mathrm{NH}_{4}-\mathrm{N} / \mathrm{NO}_{3}-\mathrm{N}$ index to define a compost sufficiently mature. All blends remained below the 0.16 limit for the $\mathrm{NH}_{4}-\mathrm{N} / \mathrm{NO}_{3}-\mathrm{N}$ ratio, with $\mathrm{CB} 2$ and $\mathrm{CB} 3$ giving the lowest values.

A summary of COMBI characteristics compared to the composted digestate is given in Table 8; the main parameters chosen to evaluate the quality of the materials produced by composting and co-composting were the final biochar rate, the NOM yield, the humified organic matter, the compliance with
Table 6 Product quality comparison: humification and polymerization indexes

\begin{tabular}{lllllll}
\hline Parameter & U.M. & CD & CB1 & CB2 & CB3 & Threshold [43] \\
\hline Humic acid & $\%$ w/w w.b. & 3.72 & 3.60 & 23.66 & 1.97 & - \\
Fulvic acid & $\% w / w$ w.b. & 1.54 & 1.37 & 7.87 & 5.39 & - \\
Humification Index (HI) & $\%$ & 4.0 & 3.6 & 20.0 & 13.2 & $\geq 3.5$ \\
Polymerization index (PI) & $\%$ & 2.4 & 2.6 & 3.0 & 0.4 & $\geq 1$ \\
\hline
\end{tabular}


Table 7 Product quality direct comparison: nitrogen compounds $\left(\mathrm{NH}_{4}-\mathrm{N} / \mathrm{NO}_{3}-\mathrm{N}\right.$ ratio $)$ in $\mathrm{COMBI}$ blends and digestate

\begin{tabular}{lllllll}
\hline Parameter & U.M. & $\mathrm{CD}$ & $\mathrm{CB} 1$ & $\mathrm{CB} 2$ & $\mathrm{CB} 3$ & Method \\
\hline Total N & $\% w / w$ d.b. & 4.2 & 2.8 & 2.7 & 2.4 & ANPA 13 Man 3 2001 \\
Organic-N/total N & $\%$ & 99.15 & 99.65 & 99.55 & 99.63 & ANPA 14 Man 3 2001 \\
Nitrate-N & $\% w / w$ d.b. & 0.280 & 0.100 & 0.180 & 0.130 & EPA 300.11997 \\
Ammonium-N & $\% w / w$ d.b. & 0.036 & 0.010 & 0.012 & 0.010 & ANPA 14 Man 3 2001 \\
$\mathrm{NH}_{4}-\mathrm{N} / \mathrm{NO}_{3}$-N ratio & & 0.129 & 0.100 & 0.067 & 0.077 & - \\
$\mathrm{C} / \mathrm{N}$ & & 9.55 & 15.99 & 16.80 & 21.08 & - \\
\hline
\end{tabular}

the ECN-QAS limits for inorganic pollutants, and the product stabilization and sanitization indexes.

\section{Conclusions}

A production test of COMBI for field trial application was carried out in this study. The control (CD) was prepared by composting solid digestate only with straw; CB2 blend was prepared considering a field application of $3 \mathrm{tha}^{-1}$, while $\mathrm{CB} 1$ and $\mathrm{CB} 3$ blends were prepared with $\mathrm{a} \pm 30 \% \mathrm{w} / \mathrm{w}$ w.b. respect to the initial biochar content in CB2.

The experimental work led to a biochar concentration in the final product of $14.9,19.8,22.8 \% \mathrm{w} / \mathrm{w}$ d.b. The difficulty in estimating the final biochar concentration by weight on dry basis during COMBI production was an outcome of the production run. Indeed, when COMBI is directly produced in field conditions, the uncertainties in measuring the moisture content of different samples of the solid fraction of digestate influence the mass yield prediction, which is also dependent on local climatic conditions.

The composting process was carried out with a biochar concentration in the initial blend of at least $11.2 \% \mathrm{w} / \mathrm{w}$ d.b.; CB2 and CB3 ended the bio-oxidative phase about 4 days earlier than $\mathrm{CD}$ and $\mathrm{CB} 1$. At the same time, biochar addition did not increase the peak temperature of the co-composting process, as also reported in literature. The process parameter condition ( 10 days over $55^{\circ} \mathrm{C}$ ) to guarantee the sanitization, indeed, was obtained only for CD and CB2. However, as regards a potential contamination by pathogens, only CB3 resulted with a $E$. coli proliferation $\left(10^{4} \mathrm{UFC}^{-1}\right)$.

The compost obtained from the control (CD) met all main reference limits, but products characteristics, in terms of a quantitative comparison with $\mathrm{CB} 2$, were always lower, in particular, regarding the product stabilization obtained.

CB2 blend, having an initial biochar concentration of $11.2 \% \mathrm{w} / \mathrm{w}$ d.b., attained a final concentration of $19.8 \% \mathrm{w} / \mathrm{w}$ d.b.: it outperformed the other blends on all process and product parameters, showing the lowest stabilization time, the highest NOM yield with the highest degree of humification, and the lowest ammonium/nitrate ratio index. This result suggests that the $11.2 \% \mathrm{w} / \mathrm{w}$ d.b. initial rate of biochar in the blend maximized the synergistic effect of co-composting the solid fraction of digestate with biochar. In field conditions, especially at larger scale of composting operations (e.g., anaerobic digestion plants), this rate should be further screened to increase process efficiency.

Furthermore, it can be speculated that, if applied to soil as an amendment, CB2 could outperform the other blends in terms of OM increase in soil, considering its humification rate; however, this has to be further investigated in agronomic field trials. Stability of the recalcitrant carbon contained in biochar
Table 8 Product quality comparison: all the results obtained summarized

\begin{tabular}{lllll}
\hline Parameter & $\mathrm{CD}$ & $\mathrm{CB} 1$ & $\mathrm{CB} 2$ & $\mathrm{CB} 3$ \\
\hline Final biochar rate $\% w / w$ d.b. & 0 & 14.9 & 19.8 & 22.8 \\
Reduction of processing time & Control & No reduction & $\sim 4$ days & $\sim 4$ days \\
Sanitization $\left(10\right.$ days over $\left.55^{\circ} \mathrm{C}\right)$ & Yes & No & Yes & No \\
Pathogens contamination & No & No & No & E. coli \\
ECN-QAS limit observance & Yes & Yes & Yes & Yes \\
Net organic matter yield $\%$ & 38.5 & 41.8 & 47.1 & 56.3 \\
PDRI mg $\mathrm{O}_{2}$ kg ${ }^{-1} \mathrm{~h}^{-1}(<300)$ & $<300$ & 350 & $<200$ & $<200$ \\
Humification Index $(\mathrm{HI})(>3.5 \%)$ & 4.0 & 3.6 & 20.0 & 13.2 \\
Polymerization index $(\mathrm{PI})(>1.0 \%)$ & 2.4 & 2.6 & 3.0 & 0.4 \\
$\mathrm{NH}_{4}$-N $\%$ w $w$ d.b. $(<0.04 \%)$ & 0.036 & 0.010 & 0.012 & 0.010 \\
$\mathrm{NH}_{4}-\mathrm{N} / \mathrm{NO}_{3}$-N ratio $(<0.16)$ & 0.129 & 0.100 & 0.067 & 0.077 \\
\hline
\end{tabular}


can also contribute to the carbon sink of soil for the mitigation of greenhouse gas emissions.

A qualitative result of the experiment which should be highlighted is dust reduction in biochar: after mixing the windrows, the typical black dust that normally develops when handling biochar, could not be visually observed. This represents a tremendous advantage in terms of logistics, handling, health, and safety of biochar, when it is transported, stored and applied to fields.

The results from the present work suggests that the role of biochar in co-composting of digestate is relevant and consistent with literature for other organic substrates. In particular, considering carrying out the operations in field conditions of an anaerobic digestion plant, it is important to underline the benefit observed regarding the time reduction needed by the process, also corresponding to a product with better characteristics than without biochar addition.

Two of the main parameters investigated for COMBI characterization were the biochar rate and the NOM content. An application rate based on weight per hectare on wet basis could be misleading due to the possible uncertainties in sample collection and representativity, as regards the moisture content. The adoption of a volume-based approach, instead, allows for a better evaluation of the actual biochar application rate per hectare.

Further research on the co-composting of biochar and digestate could include mass balance of nitrogen and carbon through measuring of gaseous emissions from windrows, to establish also greenhouse gas emissions of the process. The use of lysimeters is thus recommended for the scope. Since C/ $\mathrm{N}$ ratio normally used in agriculture is difficult to apply to cocomposted blends with biochar for agronomic application, further investigation on water-soluble $\mathrm{C} / \mathrm{N}$ of the final product is suggested.

Funding information This project received funding from the European Union's Horizon 2020 research and innovation program under grant agreement BIO4A-No 789562. The authors also wish to acknowledge Silvia Pennazzi, Giulia Lotti and Lorenzo Bettucci from RE-CORD lab for the analytical work on feedstocks and products, as well as Pietro Rampini and his staff for their availability during the preparation of COMBI in the greenhouse.

Open Access This article is distributed under the terms of the Creative Commons Attribution 4.0 International License (http:// creativecommons.org/licenses/by/4.0/), which permits unrestricted use, distribution, and reproduction in any medium, provided you give appropriate credit to the original author(s) and the source, provide a link to the Creative Commons license, and indicate if changes were made.

\section{References}

1. Li H, Mehmood D, Thorin E, Yu Z (2017) Biomethane production via anaerobic digestion and biomass gasification. Energy Procedia 105:1172-1177. https://doi.org/10.1016/j.egypro.2017.03.490
2. Ardolino F, Parrillo F, Arena U (2018) Biowaste-to-biomethane or biowaste-to-energy? An LCA study on anaerobic digestion of organic waste. J Clean Prod 174:462-476. https://doi.org/10.1016/j. jclepro.2017.10.320

3. Khanal SK (2008) Overview of anaerobic technology. In: Khanal SK, Jones CS (eds) Anaerobic biotechnology for bioenergy production: principles and applications. Wiley-Blackwell, pp 1-32

4. Gajalakshmi S, Abbasi SA (2008) Solid waste management by composting: state of the art. Crit Rev Environ Sci Technol 38: 311-400. https://doi.org/10.1080/10643380701413633

5. Lim LY, Bong CPC, Lee CT et al (2017) Review on the current composting practices and the potential of improvement using twostage composting. Chem Eng Trans 61:1051-1056. https://doi.org/ 10.3303/CET1761173

6. Raza S, Ahmad J (2016) Composting process: a review. Int J Biol Res 4:102. https://doi.org/10.14419/ijbr.v4i2.6354

7. Zeng Y, De Guardia A, Dabert P (2016) Improving composting as a post-treatment of anaerobic digestate. Bioresour Technol 201:293303. https://doi.org/10.1016/j.biortech.2015.11.013

8. Tambone F, Terruzzi L, Scaglia B, Adani F (2015) Composting of the solid fraction of digestate derived from pig slurry: biological processes and compost properties. Waste Manag 35:55-61. https:// doi.org/10.1016/j.wasman.2014.10.014

9. Bustamante MA, Restrepo AP, Alburquerque JA, Pérez-Murcia MD, Paredes C, Moral R, Bernal MP (2013) Recycling of anaerobic digestates by composting: effect of the bulking agent used. J Clean Prod 47:61-69. https://doi.org/10.1016/j.jclepro.2012.07. 018

10. Viaene J, Reubens B, Willekens K, van Waes C, de Neve S, Vandecasteele B (2017) Potential of chopped heath biomass and spent growth media to replace wood chips as bulking agent for composting high N-containing residues. J Environ Manag 197: 338-350. https://doi.org/10.1016/j.jenvman.2017.03.086

11. Kwapinski W, Byrne CMP, Kryachko E, Wolfram P, Adley C, Leahy JJ, Novotny EH, Hayes MHB (2010) Biochar from biomass and waste. Waste and Biomass Valorization 1:177-189. https://doi. org/10.1007/s12649-010-9024-8

12. Weber K, Quicker P (2018) Properties of biochar. Fuel 217:240 261. https://doi.org/10.1016/j.fuel.2017.12.054

13. Agegnehu G, Srivastava AK, Bird MI (2017) The role of biochar and biochar-compost in improving soil quality and crop performance: a review. Appl Soil Ecol 119:156-170. https://doi.org/10. 1016/j.apsoil.2017.06.008

14. Lehmann J, Joseph S (2009) Biochar for environmental management: an introduction. In: Lehmann J, Joseph S (eds) Biochar for Environmental Management: Science and Technology. Earthscan, pp 1-12

15. Sánchez-García M, Alburquerque JA, Sánchez-Monedero MA, Roig A, Cayuela ML (2015) Biochar accelerates organic matter degradation and enhances $\mathrm{N}$ mineralisation during composting of poultry manure without a relevant impact on gas emissions. Bioresour Technol 192:272-279. https://doi.org/10.1016/j. biortech.2015.05.003

16. Xiao R, Awasthi MK, Li R, Park J, Pensky SM, Wang Q, Wang JJ, Zhang Z (2017) Recent developments in biochar utilization as an additive in organic solid waste composting: a review. Bioresour Technol 246:203-213. https://doi.org/10.1016/j.biortech.2017.07. 090

17. Zhang J, Lü F, Shao L, He P (2014) The use of biochar-amended composting to improve the humification and degradation of sewage sludge. Bioresour Technol 168:252-258. https://doi.org/10.1016/j. biortech.2014.02.080

18. Godlewska P, Schmidt HP, Ok YS, Oleszczuk P (2017) Biochar for composting improvement and contaminants reduction. A review. Bioresour Technol 246:193-202. https://doi.org/10.1016/j. biortech.2017.07.095 
19. Leng L, Huang H, Li H, Li J, Zhou W (2019) Biochar stability assessment methods: a review. Sci Total Environ 647:210-222. https://doi.org/10.1016/j.scitotenv.2018.07.402

20. Oldfield TL, Sikirica N, Mondini C, López G, Kuikman PJ, Holden NM (2018) Biochar, compost and biochar-compost blend as options to recover nutrients and sequester carbon. J Environ Manag 218:465-476. https://doi.org/10.1016/j.jenvman.2018.04.061

21. Snyder JC, Rochelle LK, Marion S, Lyerly HK, Barak LS, Caron MG (2015) Lgr4 and Lgr5 drive the formation of long actin-rich cytoneme-like membrane protrusions. J Cell Sci 128:1230-1240. https://doi.org/10.1242/jcs.166322

22. Zhao C, Chen B, Yang J (2014) Embodied water consumption of biogas-digestate utilization. Energy Procedia 61:615-618. https:// doi.org/10.1016/j.egypro.2014.11.1183

23. Lukehurst C, Frost P, AL Seadi T (2010) Utilisation of digestate from biogas plants as biofertiliser. IEA Bioenergy Task 3, pp 1-36

24. Al Seadi T, Drosg B, Fuchs W, Rutz Z, Janssen R (2013) Biogas digestate quality and utilization. In: Wellinger A, Murphy J, Baxter $\mathrm{D}$ (eds) The biogas handbook: science, production and applications. Woodhead Publishing, pp 267-301

25. Schmidt HP, Bucheli T, Kammann C, Glaser B, Abiven S, Leifeld J (2018) European Biochar Certificate - Guidelines for a sustainable production of biochar v6.2. https://doi.org/10.13140/RG.2.1.4658. 7043

26. Siebert S, Vanden Auweele W (2018) Quality manual, ECN - QAS European Quality Assurance Scheme for Compost and Digestate. Siebert S (eds) European Compost Network

27. Rizzo AM, Pettorali M, Nistri R, Chiaramonti D (2019) Mass and energy balances of an autothermal pilot carbonization unit. Biomass Bioenergy 120:144-155. https://doi.org/10.1016/j.biombioe.2018. 11.009

28. Pettorali M (2018) Biomass carbonization in fixed-bed oxidative reactor: experimental campaign and technological developments (Doctoral dissertation thesis). Dept. of Industrial Engineering, University of Florence. Retrieved from http:/hdl.handle.net/2158/ 1127793

29. Lehmann J, Joseph S (2015) Biochar for environmental management: science, technology and implementation. Lehmann J, Joseph S (eds) Routhledge, Paris. https://doi.org/10.4324/9780203762264

30. Brassard P, Godbout S, Raghavan V (2016) Soil biochar amendment as a climate change mitigation tool: key parameters and mechanisms involved. J Environ Manag 181:484-497. https://doi.org/ 10.1016/j.jenvman.2016.06.063

31. Calvelo Pereira R, Kaal J, Camps Arbestain M, Pardo Lorenzo R, Aitkenhead W, Hedley M, Macías F, Hindmarsh J, Maciá-Agulló JA (2011) Contribution to characterisation of biochar to estimate the labile fraction of carbon. Org Geochem 42:1331-1342. https:// doi.org/10.1016/j.orggeochem.2011.09.002

32. Bishop PL, Godfrey C (1983) Nitrogen transformations during sludge composting. Biocycle 24:34-39

33. Bernal MP, Alburquerque JA, Moral R (2009) Composting of animal manures and chemical criteria for compost maturity assessment. A review. Bioresour Technol 100:5444-5453. https://doi. org/10.1016/j.biortech.2008.11.027
34. Insam H, de Bertoldi $M$ (2007) Chapter 3 Microbiology of the composting process. In: Diaz LF, de Bertoldi M, Bidlingmaier W, Stentiford E (eds) Waste Management Series. pp 25-48. https://doi. org/10.1016/S1478-7482(07)80006-6

35. Das K, Keener HM (1997) Moisture effect on compaction and permeability in composts. J Environ Eng 123:275-281. https:// doi.org/10.1061/(ASCE)0733-9372(1997)123:3(275)

36. Martín-Gil J, Navas-Gracia LM, Gómez-Sobrino E et al (2008) Composting and vermicomposting experiences in the treatment and bioconversion of asphaltens from the prestige oil spill. Bioresour Technol 99:1821-1829. https://doi.org/10.1016/j. biortech.2007.03.031

37. Sugawara E, Nikaido H (2014) Properties of AdeABC and AdeIJK efflux Systems of Acinetobacter baumannii compared with those of the AcrAB-TolC system of Escherichia coli. Antimicrob Agents Chemother 58:7250-7257. https://doi.org/10.1128/AAC.03728-14

38. Miller FC (1993) Composting as a process based on the control of ecologically selective factors. In: Metting FB (ed) Soil microbial ecology: applications in agricultural and environmental management. Marcel Dekker Inc., New York, NY, pp: 515-544

39. Hao X, Chang C, Larney FJ (2013) Carbon, nitrogen balances and greenhouse gas emission during cattle feedlot manure composting. J Environ Qual 33. https://doi.org/10.2134/jeq2004.3700

40. Garrison MV, Richard T, Tiquia-Arashiro SM, Honeyman MS (2001) Nutrient losses from unlined bedded swine hoop structures and an associated windrow composting site. In: ASAE Annual International Meeting. pp 13-14. https://doi.org/10.13031/2013. 4202

41. US Department of Agriculture Composting Council Research and Education Foundation (2002) Test methods for the examination of composting and compost. Rokonkoma, NY

42. Sánchez-Monedero MA, Cegarra J, García D, Roig A (2002) Chemical and structural evolution of humic acids during organic waste composting. Biodegradation 13:361-371. https://doi.org/10. 1023/A:1022888231982

43. Roletto E, Consiglio M, Jodice R, Barberis R (1985) Chemical parameters for evaluating compost maturity. Biocycle 26:46-47

44. Senesi N (1989) Composted materials as organic fertilizers. Sci Total Environ 81-82:521-542. https://doi.org/10.1016/00489697(89)90161-7

45. Zucconi F and De Bertoldi M (1987) Compost specifications for the production and characterization of compost from municipal solid waste. In: De Bertoldi, M., Ferranti, M.P., L'Hermite, M.P. and Zucconi F (ed) Compost: production, quality and use. Elsevier, London, pp 276-295

46. Bernai MP, Paredes C, Sánchez-Monedero MA, Cegarra J (1998) Maturity and stability parameters of composts prepared with a wide range of organic wastes. Bioresour Technol 63:91-99. https://doi. org/10.1016/S0960-8524(97)00084-9

Publisher's note Springer Nature remains neutral with regard to jurisdictional claims in published maps and institutional affiliations. 